\title{
MODEL PENANGANAN ANAK JALANAN DI KOTA PALANGKA RAYA
}

\author{
Fauzi Rahman \\ Fakultas IImu Sosial dan IImu Politik Universitas PGRI Palangka Raya \\ (email: jibranfauzi05@gmail.com)
}

\begin{abstract}
Abstrak
Penelitian ini bertujuan untuk a) Ingin mengetahui peran Dinas Sosial Kota Palangka Raya dalam penanganan anak jalanan berbasis Keluarga diKota Palangka Raya. b) Ingin mendeskripsikan tentang: Profil (potret) anak jalanan dan keluarganya; Faktor-faktor penyebab munculnya anak jalanan; Peta permasalahan anak jalanan; Pandangan masyarakat tentang anak jalanan; dan Beberapa model alternatif yang mungkin dapat diterapkan dalam penanganan anak jalanan yang berbasis keluarga di Kota Palangka Raya.

Jenis penelitian yang digunakan adalah Penelitian deskriptif dengan menggunakan pendekatan kualitatif.

Hasil penelitian ini dapat disimpulkan : 1) Peran Dinas Sosial Kota Palangka Raya dalam penanganan anak jalanan berdasarkan Peraturan Daerah kota Palangka Raya Nomor 16 Tahun 2007 belum dilaksanakan secara maksimal hal ini berhubungan dengan kesungguhan pemerintah daerah dalam mengalokasikan anggaran yang kurang memadai. 2) Penanganan anak jalanan dalam teori dramaturgi memaparkan peran dari petugas sebagai pembina sekaligus pengasuh anak jalanan dapat menjadi jenis alternatif dalam merubah perilaku anak jalanan.
\end{abstract}

\section{Kata kunci : Model Penanganan Anak Jalanan}

\section{Pendahuluan}

Gejala merebaknya anak jalanan di Indonesia merupakan persoalan sosial yang komplek. Hidup menjadi anak jalanan memang bukan merupakan pilihan yang menyenangkan, karena mereka berada dalam kondisi yang tidak bermasa depan jelas, dan keberadaan mereka tidak jarang menjadi "masalah" bagi banyak pihak, keluarga, masyarakat dan negara. Namun, perhatian terhadap nasib anak jalanan tampaknya belum begitu besar dan solutif. Padahal mereka adalah saudara kita. Mereka adalah manusia Indonesia yang harus dilindungi, dijamin hakhaknya, sehingga tumbuh-kembang menjadi manusia dewasa yang bermanfaat, beradab dan bermasa depan cerah.

Menurut UUD 1945, “anak terlantar itu dipelihara oleh negara". Artinya pemerintah mempunyai tanggung jawab terhadap pemeliharaan dan

\section{Jurnal Sociopolitico}


pembinaan anak-anak terlantar, termasuk anak jalanan. Hak-hak asasi anak terlantar dan anak jalanan, pada hakekatnya sama dengan hak-hak asasi manusia pada umumnya, seperti halnya tercantum dalam UU No. 39 tahun 1999 tentang Hak Asasi Manusia, dan Keputusan Presiden RI No. 36 Tahun 1990 tentang Pengesahan Convention on the Right of the Child (Konvensi tentang hak-hak Anak). Mereka perlu mendapatkan hak-haknya secara normal sebagaimana layaknya anak, yaitu hak sipil dan kemerdekaan (civil righ and freedoms), lingkungan keluarga dan pilihan pemeliharaan (family envionment and alternative care), kesehatan dasar dan kesejahteraan (basic health and welfare), pendidikan, rekreasi dan budaya (education, laisure and culture activites), dan perlindungan khusus (special protection).

Kementerian Sosial Republik Indonesia mencatat dari tahun ke tahun terdapat pengurangan anak jalanan di seluruh wilayah Indonesia. Dari 33.400 anak pada 2015, jumlahnya menurun menjadi 20.719 anak pada 2016. Kemudian turun menjadi 16.416 anak pada 2017.

Walaupun terjadi pengurangan setiap tahunnya namun pada hakekatnya permasalahan anak jalanan masih menjadi pekerjaan rumah yang sangat serius, bahwa ketika menengok kebelakang dari hasil Survei Sosial Ekonomi Nasional (SUSENAS) Badan Pusat Statistik Republik Indonesia tahun 1998 memperlihatkan bahwa anak jalanan secara nasional berjumlah sekitar 2,8 juta anak. Dua tahun kemudian, tahun 2000, angka tersebut mengalami kenaikan sekitar 5,4\%, sehingga jumlahnya menjadi 3,1 juta anak. Pada tahun yang sama, anak yang tergolong rawan menjadi anak jalanan berjumlah 10,3 juta anak atau 17, $6 \%$ dari populasi anak di Indonesia, yaitu 58,7 juta anak (Soewignyo, 2002). Dari Pusdatin Depsos RI (2007) Anak diexplotasi Anak diterlantarkan 3.940.300 anak, Anak korban tindak kekerasan Anak nakal berjumlah 203.151 orang sedangkan anak korban Pelecehan Seksual Anak jalanan 104.497 anak

Angka-angka tersebut menunjukkan bahwa kualitas hidup dan masa depan anak-anak sangat memperihatinkan, padahal mereka adalah aset, investasi SDM dan sekaligus tumpuan masa depan bangsa. Jika kondisi dan kualitas hidup anak kita memprihatinkan, berarti masa depan bangsa dan negara juga kurang menggembirakan. Bahkan, tidak tertutup kemungkinan, sebagian dari anak bangsa kita mengalami lost generation (generasi yang hilang).

SUSENAS tahun 2000 juga menunjukkan bahwa salah satu faktor ketidakberhasilan pembangunan nasional dalam berbagai bidang itu, antara lain, disebabkan oleh minimnya perhatian pemerintah dan semua pihak terhadap eksistensi keluarga. Perhatian dan treatment yang terfokus pada "keluarga sebagai basis dan sistem pemberdayaan" yang menjadi pilar utama kehidupan berbangsa dan bernegara relatif belum menjadi komitmen bersama dan usaha yang serius dari banyak pihak. Padahal, masyarakat dan negara yang sehat, kuat, cerdas, dan berkualitas dipastikan karena tumbuh dan berkembang dari dan dalam lingkungan keluarga yang sehat, kuat, cerdas dan berkualitas. Dengan demikian, masalah anak termasuk anak jalanan perlu adanya penanganan yang berbasis keluarga, karena keluarga adalah 
penanggung jawab pertama dan utama masa depan anak-anak mereka.

Menurut pengamatan kami, penanganan anak jalanan di seluruh wilayah Indonesia pada umumnya belum mempunyai model dan pendekatan yang tepat dan efektif. Keberadaan Rumah Singgah misalnya, menurut hasil penelitian Badan Pelatihan dan Pengembangan Sosial Depsos (2003), dinilai kurang efektif karena tidak menyentuh akar persoalan, yaitu kemiskinan dalam keluarga "(Kompas, 26 Pebruari 2003). Pembinaan dan pemberdayaan pada lingkungan keluarga tempat mereka tinggal tampaknya belum banyak dilakukan, sehingga penanganannya selama ini cenderung "tambal sulam" dan tidak efektif. Sementara itu, keluarga merupakan "pusat pendidikan, pembinaan dan pemberdayaan pertama" yang memungkinkan anak-anak itu tumbuh dan berkembang dengan baik, sehat dan cerdas. Pemberdayaan keluarga dari anak jalanan, terutama dari segi ekonomi, pendidikan dan agamanya, diasumsikan merupakan basis utama dan model yang efektif untuk penanganan dan pemberdayaan anak jalanan.

Anak jalanan di Provinsi Kalimantan Tengah, sebagai salah satu kasus, berjumlah 39,855 anak, sedangkan Panti asuhan yang memberikan pelayanan sosial terhadap mereka sangat terbatas. Daya tampung keseluruhannya adalah 560 anak. Sementara itu, Panti Sosial Asuhan Anak yang diselenggarakan masyarakat Secara akumulatif jumlah yang yang mendapat pelayanan Panti dan non-Panti adalah 8.908 anak dan yang belum tersentuh pelayanan pemerintah maupun organisasi sosial atau LSM adalah 30.387 anak (Dinas Sosial Pemerintah Propinsi Kalteng, 2008).

\section{Jurnal Sociopolitico}

Fakultas Ilmu Sosial dan Ilmu Politik
Persebaran anak jalanan di Kota Palangka Raya juga cukup merata. Data yang diterbitkan oleh Dinas Sosial Kota Palangka Raya menyebutkan dalam kurun waktu tiga tahun terakhir dari tahun 2016 sampai tahun 2018 adalah seperti dalam tabel berikut :

Tabel 1

Anak Jalanan

\begin{tabular}{|c|c|c|c|}
\hline No & Tahun & Dalam Kota & Ket \\
\hline 1 & 2016 & 15 & \\
\hline 2 & 2017 & 6 & \\
\hline 3 & 2018 & 16 & \\
\hline & & 37 & \\
\hline
\end{tabular}

Sumber : Dinas Sosial Kota Palangka Raya Maret 2018

Data tersebut cukup memperihatinkan kita semua, karena idealnya sebagai "kota percontohan" Palangka Raya dapat bebas dari masalah anak jalanan, atau setidak-tidaknya jumlah anak jalanan tergolong rendah di seluruh propinsi di Indonesia. Selama ini, penanganan anak jalanan melalui pantipanti asuhan dan rumah singgah dinilai tidak efektif. Hal ini antara lain terlihat dari "pola asuh" yang cenderung konsumtif, tidak produktif karena yang ditangani adalah anak-anak, sementara keluarga mereka tidak diberdayakan.

Berdasarkan latar belakang pemikiran tersebut, Penelitian dilakukan dalam rangka mencari "Solusi Yang Efektif Dalam Penanganan Anak" di Kota Palangka Raya yang Berbasis Pada Pemberdayaan Keluarga.

Kesungguhan Pemerintah Kota Palangka Raya dalam menangani kasus anak jalanan masih perlu dipertanyakan walaupun peraturan daerah telah diterbitkan. Pertanyaan pokok masalah tersebut adalah :

1. Bagaimanakah peran Dinas Sosial Kota Palangka Raya dalam penanganan anak jalanan? 
2. Bagaimanakah Model Dalam Penanganan Anak Jalanan" di Kota Palangka Raya yang Berbasis Pada Pemberdayaan Keluarga dan dalam teori dramaturgi?

\section{Metode Penelitian}

Jenis penelitian yang digunakan adalah Penelitian deskriptif dengan menggunakan pendekatan kualitatif. Pendekatan kualitatif menurut Strauss dan Corbin dalam Soewadji (2012;51). adalah penelitian yang menghasilkan penemuan-penemuan yang tidak dapat dicapai (diperoleh) dengan menggunakan prosedur-prosedur statistik atau cara-cara dari kuantifikasi (pengukuran).

Menurut Lexy J. Moleong (2009:5) dan John W. Creswell (1997:3), pendekatan kualitatif merupakan prosedur penelitian yang menghasilkan data deskriptif berupa katakata tertulis atau lisan dari orang-orang dan perilaku yang diamati. Yang membedakan antara pendekatan kualitatif dan pendekatan kuantitatif adalahh asumsi filosofis yang dibawa peneliti ke dalam penelitiannya, jenis strategi yang digunakan peneliti, dan metode spesifik yang diterapkan untuk melaksanakan strateginya. Pendekatan kualitatif tidak mencari hubungan atau pengaruh antar variabel- variabel tetapi untuk memperoleh pemahaman lebih mendalam mengenai suatu fenomena, sehingga akan dapat diperoleh teori.

\section{Hasil dan Pembahasan}

Peran Dinas Sosial Kota Palangka Raya dalam penanganan Anak Jalanan Sesuai Peraturan Daerah Nomor 16 Tahun 2007

\section{Realitas Kehidupan Anak Jalanan}

Sebagaimana diamanatkan dalam peraturan daerah Nomor 16 Tahun 2007 bahwa kegiatan khususnya anak jalanan di Kota Palanga Raya bertentangan dengan norma-norma kemasyarakatan ( Bab II Pasal 2 ).

Alasan utama adalah bahwa anak jalanan adalah fenomena sosial yang mencemaskan dunia (Suharto, 2007; 231). Dimana pelaku berusia paling banyak berusia dibawah 10 tahun. Anak jalanan bertahan hidup dengan melakukan aktivitas di sektor informal seperti menyemir sepatu, menjual koran, mencuci kendaraan, menjadi pemulung barangbarang bekas, yang lebih parah lagi adalah mengemis, mengamen, mencuri, mencopet, atau terlibat dalam perdagangan sex.

Di jalan mereka memiliki pengalaman buruk dengan Polisi Pamong Praja, Penanganan yang dilakukan oleh pemerintah lebih sering bersifat sementara dan tindakan kekerasan yang menimbulkan trauma.

Kehidupan anak jalanan di lingkungan masyarakat tidak jauh dari berbagai macam kekerasan. Kekerasan rumah tangga sering terjadi dalam keluarga miskin, dimana pelaku nya adalah orang dekat seperti orangtua anak. Hak anak untuk hidup dalam keceriaan dilanggar setiap hari oleh orang tua sendiri. Anak-anak diekploitasi, di pekerjakan dalam lingkungan yang buruk, dan berbagai diskriminasi masih sangat sering dijumpai terutama dikota dan dalam keluarga miskin.karena miskin maka anak dipaksa mengemis di jalanan.

Kepedulian terhadap anak jalanan terutama didasari kenyataan bahwa anak adalah aset bangsa yang memiliki hak

\section{Jurnal Sociopolitico}


untuk tumbuh dan berkembang, sementara itu hidup dijalanan sangat membahayakan. Mereka seringkali menjadi sasaran pemaksaan ekonomi oleh orang dewasa ( termasuk orang tua anak ), rentan terhadap kekerasan fisik, sosial, dan seksual, dan menurut hasil pengamatan media koran media massa, mereka dipaksa untuk terlibat dalam jaringan narkoba.

Pada umumnya anak jalanan tidak hidup bersama keluarganya, tidak bersekolah, dan tidak memiliki orang dewasa atau lembaga yang merawat mereka.kemiskinan di yakini menjadi alasan menyuruh mereka bekerja, selain itu keluarga yang tidak harmonis , ditelantarkan oleh keluarganya atau karena mengalami tindak kekerasan dalam rumah tangga (dalam Suharto; 2007; 233).

\section{Proses Penanganan yang dilakukan}

Fokus utama pembangunan kesejahteraan sosial adalah pada perlindungan sosial, oleh karenanya model pertolongan terhadap anak jalanan bukan sekedar menghapus anak dari jalanan.melainkan harus bisa meningkatkan kualitas hidup mereka atau sekurang-kurangnya melindungi mereka dari situasi-situasi yang ekploitatif dan membahayakan.

Pemerintah kota Palangka Raya melalui Dinas Sosial dalam melaksanakan kegiatan berpegang kepada aturan Peraturan Daerah Kota Palangka Raya Nomor 16 Tahun 2007 dimana kegiatan yang dilakukan yaitu :

1. Pelayanan sosial yaitu suatu bentuk kegiatan pelaksanaan usaha dan kegiatan kesejahteraan yang ditangani secara terorganisasi, sistematik dan profesional

2. Rehabilitasi yaitu upaya-upaya yang terorganisir melalui usaha-usaha penyantunan, pemberian bimbingan motivasi, pendidikan dan pelatihan, pemulihan kemampuan, penyaluran kembali kemasyarakat,pengawasan maupun pembinaan lanjut sehingga kembali memiliki kemampuan untuk hidup secara layak dan wajar sesuai dengan harkat dan martabat manusia.

3. Resosialisasi adalah segaala upaya terorganisir dengan tujuan membaurkan kembali ke lingkungan sosialnya, baik pribadi, anggota keluarga maupun masyarakat.

Adapun alur kegiatan selama ini dapat dijelaskan sebagai berikut :

1. Pemprograman kegiatan dimasukkan dalam anggaran dan belanja daerah Kota Palangka Raya. hal ini dilakukan dalam rangka upaya operasionalisasi dilapangan yang cukup banyak melibatkan personil dan terkait dengan biaya.

2. Penyerapan informasi anak jalanan Data dan informasi tentang keberadaan anak jalanan sangat penting dalam menetapkan langkah yang akan diambil dengan tetap berkoordinasi dengan aparat terkait.

3. Melakukan razia ditempat yang telah terindentifkasi

4. Assesment dan indentifikasi terhadap anak jalanan yang terjaring

5. Bimbingan motivasi

6. Pemberian santunan

7. Dikembalikan ketempat orang tua atau panti asuhan untuk mendapat pembinaan lanjutan.

Dari alur kegiatan diatas biasanya hasil razia hanya dapat di bina selama 3 hari , hal yang sangat mustahil untuk merubah perilaku anak jalanan. Selama ini hasil pembinaan kurang memuaskan,

\section{Jurnal Sociopolitico}


selain pendeknya waktu yang berkaitan dengan masalah pendanaan harus sesuai dengan pagu anggaran yang ada.

Di lain pihak ada kecenderungan dari anak jalanan kembali ke jalanan lagi ( beberapa hasil razia mendapati orang yang sama ). Permasalahan kesejahteraan sosial yang berkembang tersebut menunjukkan bahwa ada warga negara yang belum terpenuhi hak atas kebutuhan dasarnya secara layak karena belum memperoleh pelayanan sosial dari negara. Akibatnya, masih ada warga negara yang mengalami hambatan pelaksanaan fungsi sosial sehingga tidak dapat menjalani kehidupan secara layak dan bermartabat.

Padahal Pasal 34 ayat (1) UndangUndang Dasar Negara Republik Indonesia Tahun 1945 mengamanatkan kewajiban negara untuk memelihara fakir miskin dan anak terlantar. Bagi fakir miskin dan anak terlantar seperti yang dimaksud dalam Undang-Undang Dasar Negara Republik Indonesia Tahun 1945, Pemerintah dan pemerintah daerah memberikan rehabilitasi sosial, jaminan sosial, pemberdayaan sosial, dan perlindungan sosial sebagai perwujudan pelaksanaan kewajiban negara dalam menjamin terpenuhinya hak atas kebutuhan dasar warga negara yang miskin dan tidak mampu.

Pelaksanaan Pembinaan Anak Jalanan dalam Teori Dramaturgi Erving Goffman

$\begin{array}{llll} & \text { Fokus pendekatan dramaturgis } \\ \text { adalah bukan apa yang orang lain }\end{array}$ lakukan, bukan apa yang ingin mereka lakukan, atau mengapa mereka melakukan, melainkan bagaimana mereka melakukan. Oleh sebab itu peran peneliti berusaha melihat bagaimana peran Dinas Sosial dalam pembinaan anak jalanan. Pekerja Sosial yang dimaksudkan oleh peneliti adalah pembina dan pendamping anak jalanan di Dinas Sosial Kota Palangka Raya.

\section{Pemahaman Panggung}

Tujuan dari presentasi dari Diri Goffman ini adalah penerimaan penonton akan manipulasi. Bila seorang aktor berhasil, maka penonton akan melihat aktor sesuai sudut yang memang ingin diperlihatkan oleh aktor tersebut. Dari sini dramaturgi mempelajari konteks dari perilaku manusia dalam mencapatujuannya dan bukan untuk mempelajari hasil dari perilakunya tersebut. Hal ini juga di lakukan oleh para pembimbing dan pendamping, mereka berusaha menerjemahkan siapa yang mereka hadapi. Mereka mempelajari panggung (karakter) yang dimiliki oleh anak-anak jalanan.

"Kita harus bisa berperan kepada siapa yang kita hadapi. Karena 1 anak disini seperti 10 anak rumahan. Kalau kita lengah sedikit saja, kita bisa kemakan sama mereka, dipermainkan sama mereka." (Wawancara dengan Pekerja Sosial )

Dengan mempelajari panggung (karakter) sebelum memulai pementasan (pembinaan) termasuk salah satu strategi dalam menyukseskan pembinaan di Rumah singgah.

2. Menjadi Aktor

Menurut konsep dramaturgis sendiri, manusia akan mengembangkan perilaku-perilaku yang mendukung perannya tersebut. Oleh karenanya

\section{Jurnal Sociopolitico}


pertunjukan drama, seorang aktor drama kehidupan juga harus mempersiapkan kelengkapan pertunjukan dalam mencapai tujuannya tersebut. Sepertinya para pembina dan pembimbing UPTD Rumah Singgah selaku aktor juga mempersiapkan kebutuhan yang harus diperankan dalam proses pembinaan kepada anak- anak jalanan.

"Jadi untuk memberi pembelajaran kepada anak-anak kita harus bermain peran. Bagaimana kita menghadapi anak si A misalkan, lalu untuk anak B kita tidak bisa mengunakan peran yang sama juga."( Wawancara dengan Petugas Dinas Sosial)

Adanya strategi atau plan dalam pembinaan setiap anak dibuat berbeda, sesuai pendekatan yang cocok pada masing-masing anak, dapat memudahkan para pembina dan pembimbing dalam pementasan drama (sosialisasi pembinaan).

\section{Dramaturgi}

Dalam perspektif dramaturgi, kehidupan ibarat teater, yang mirip dengan pertunjukan diatas panggung, menampilkan peran-peran yang dimainkan para aktor. Menurut Goffman kehidupan sosial itu dapat dibagi menjadi wilayah depan (front region) dan wilayah belakang (back region). Wilayah depan ibarat panggung sandiwara bagian depan (front stage) yang ditonton khalayak penonton, sedang wilayah belakang ibarat panggung sandiwara bagian belakang (back stage) atau kamar rias tempat pemain sandiwara bersantai, mempersiapkan diri, atau berlatih untuk memainkan perannya di panggung depan. Begitu halnya dengan kehidupan pembina dan pembimbing anak jalanan di Rumah Singgah, terdapat panggung depan dan panggung belakang.

Panggung depan pembimbing dan pembina adalah ketika mereka yang mendadak menjadi orang tua, menjadi seorang ibu dan ayah, harus bisa terlihat tegas, dan selalu menjaga diri di waktu pembinaan terhadap anak jalanan.

Sedangkan panggung belakang pembimbing dan pembina adalah ketika mereka kembali berada di rumah, mereka menjadi anak seperti biasanya, bebas melakukan apa saja, tidak takut untuk berbuat sesukanya, atau saat mempersiapkan peran sebagaimana pembina dan pembimbing seharusnya.

Di dalam panggung depan, ada yang namanya front personal dan setting. Front personal bisa dikatakan alat-alat seperti pendukung saat melakukan pembinaan terhadap anak-anak jalanan.

"Nah lucu mas disini saya sebagai orang tua, padahal saya belum menikah sama seperti mbak hilda juga. Padahal di rumah jadi anak bapak ibu hehe... Kadang sebagai tempat curhat dari anak-anak juga."

"Disini saya harus bersifat lebih tegas, harus bisa memposisikan diri dari pada di rumah, disini tiap hari bisa marah -marah"(wawancara dengan Petugas Dinsos)

Biasanya beberapa alat pendukung untuk menjadikan pembimbing dan pembina di Kampung Anak Negeri lebih terlihat antagonis mereka membawa kayu kecil, penggaris, dan sapu. Tak hanya itu, dalam pembinaanya sering kali mereka menggunakan nada yang keras, sikap

\section{Jurnal Sociopolitico}


menakut- nakuti, dan beberapa ancaman. Dan setting yang dilakukan oleh pembimbing dan pembina ini adalah di wilayah Rumah Singgah saat mereka melakukan pembinaan.

Hal ini sangat bertolak belakang saat perilaku diperankan pembina dan pembimbing ini saat mereka berada di panggung belakang. Seperti di rumah/ atau di kantin bersama para pembina dan pembimbing lain, yang menjadi orang biasa seperti di sekitarnya, menjalani kehidupan menjadi seorang anak, tidak harus terlihat arogan, lebih santai, bisa sering bercanda dan tidak ada rasa yan terbebani. Panggung belakang juga meliputi persiapan pembimbing dan pembina dalam melakukan perencanaan pembinaan.

Dari sini pertunjukan atau pementasan yang dilakukan pembina serta pembimbing dalam pebinaan di rumah singgah sebagai upaya optimalisasi pembinaan itu sendiri. Hal ini merupakan strategi untuk mensukseskan proses sosialisasi terhadap anak-anak jalanan. oleh sebab itu perlu adanya pemeliharaan jarak terhadap anak-anak jalanan agar proses ini terus bisa berlangsung.

\section{Kesimpulan}

Peran Dinas Sosial Kota Palangka Raya dalam penanganan anak jalanan berdasarkan Peraturan Daerah kota Palangka Raya Nomor 16 Tahun 2007 belum dilaksanakan secara maksimal hal ini berhubungan dengan kesungguhan pemerintah daerah dalam mengalokasikan anggaran yang kurang memadai.

Penanganan anak jalanan dalam teori dramaturgi memaparkan peran dari petugas sebagai pembina sekaligus pengasuh anak jalanan dapat menjadi jenis alternatif dalam merubah perilaku anak jalanan.

\section{Referensi}

Anarita, Popon, dkk, 2001: Baseline Survei untuk Program Dukungan dn Pemberdayaan Anak Jalanan di Perkotaan (Bandung), Bandung: Akatiga-Pusat analisis sosial.

Arief, Armai, 2002: Upaya Pemberdayaan Anak Jalanan Dalam Rangka Mewujudkan Kesejahteraan Sosial dan Stabilitas Nasional", Dalam Jurnal Fajar, LPM UIN Jakarta, Edisi 4, No.1, November 2002.

Arijanto, Juniardi, 2002: Pemberdayaan Ekonomi Umat Melalui Masjid Sebagai Usaha Mereposisi Fungsi Masjid", dalam Jurnal Etikonomi, Jakarta: Fakultas Ekonomi dan Ilmu Sosial UIN Syarif Hidayatullah, Edisi 1, Desember 2002.

Basoeki, Badjuri,1999: Modul 1: Pelatihan Pelatih Pemberdayaan Anak Jalanan Melalui Rumah Singgah, Jakarta: Depsos bekerjasama dengan Yayasan Kesejahteraan Anak Indonesia,. 1999: Modul 2: Pelatihan Pelatih Pendampingan Orang Tua Anak Jalanan, Jakarta: Depsos bekerjasama dengan Yayasan Kesejahteraan Anak Indonesia,.

1999: Pelatihan Pelatih
Monitoring dan Evaluasi
Pemberdayaan Anak Jalanan dan
Orang Tua, Jakarta: Depsos
bekerjasama dengan Yayasan
Kesejahteraan Anak Indonesia,
Direktorat Pemberdayaan Peran Keluarga
Dirjen Pemberdayaan Sosial, 2002:,


Standarisasi Pemberdayaan Peran Keluarga, Jakarta: Depsos,.

-------, 2002: Pedoman Bimbingan Keluarga Melalui Kelompok Usaha Keluarga Muda Bina Mandiri (KUBE-KMM), Jakarta: Depsos

Gunawan, Ary H. 2010 Pengantar Sosiologi Pendidikan. Jakarta: Rineka Cipta

Kencana, Gita dkk ,2001: Baseline Survei Untuk Program Dukungan dan Pemberdayaan Anak Jalanan di Perkotaan (Medan), Medan: Warung Sahiva USU Medan.

Moleong, Alex,1995: Metode Penelitian Kualitatif, Bandung: Remaja Rosdakarya.

Mulyana. Deddy. 2000. Metodologi Penelitian Kualitatif. Bandung : PT Rosdakarya, 2000.

Muridan., U. Uswatusholilah, Khusnul Kotimah, Enung A., 2000: "Teori Diri Sebuah Tafsir Makna Simbolik (Pendekatan Teori Dramaturgi Erving Goffman)," Komunika Jurnal Dakwah dan Komunikasi, 4, no. 2 ,

Pramono, Herry, dkk, 2001: Baseline Survei Untuk Program Dukungan dan Pemberdayaan Anak Jalanan di Perkotaan (Jakarta), Jakarta: Pusat Kajian Pembangunan Masyarakat UNIKA Atma Jaya.

Ramdhani, M., Sarbaini, Harpani Matmuh. "Peran Dinas Sosial dalam Penanggulangan Anak Jalanan di Kota Banjarmasin,” 2016: Jurnal Pendidikan Kewarganegaraan: Vol 6, no 11, Mei,

Ritzer, George. 2012: Teori Sosiologi Edisi Kedelapan. Yogyakarta: Pustaka Pelajar.

Sarmanu, dkk, 2001: Baseline Survei Untuk Program Dukungan dan
Pemberdayaan Anak Jalanan di Perkotaan (Palangka Raya), Palangka Raya: Lembaga Penelitian Universitas Airlangga.

Suharto, Edi, 2007:, Kebijakan Sosial Sebagai Kebijakan Publik; Penerbit; ALPABETA. Bandung

Sunusi, Makmur, 2003: Anak Terlantar Dalam Perspektif Pekerjaan Sosial, Endang WD BM, Kebijakan Pemerintah Daerah Propinsi DKI Jakarta Dalam Penanganan Anak Terlantar, Makalah Dalam Seminar Nasional 'Penanganan Anak Terlantar Berbasis Keluarga", Jakarta: UMJ, 12 April.

Undang - Undang No. 11 tahun 2009 tentang Kesejahteraan Sosial;

Peraturan Daerah Kota Palangka Raya Nomor 16 Tahun 2007 Tentang Penanganan Gelandangan, Pengemis, Tuna Susila Dan Anak Jalanan.

\section{Jurnal Sociopolitico}

